\title{
CHAULMOOGRA OIL IN THE TREATMENT OF CHRONIC ARTHRITIS.
}

By ERNEST FLETCHER, M.A., M.B. (Camb.), M.R.C.P. (Lond.).

(Physician to E.M.S. and to Queen Mary's Hospital for the East End, Stratford; Assistant Physician to the British Red Cross Clinic for Rheumatism and (with Physical Medicine) to the Royal Free Hospital; Heberden Medallist and Lecturer in 1939.)

This fat, expressed from the seeds of East Indian trees of the genus Taraktogenos and Hydnocarpus, consists of the glyceryl esters of a series of cyclic fatty acids, which are unique in that they contain a closed 5 carbon ring, are optically active and have not been found in any other oils.

The two principal acids are chaulmoogric acid and hydnocarpic acid, and the oil contains small quantities of other homologues. Other cyclic fatty acids have been synthesised.

The natural oil and synthesised fatty acids have been found to be effective against the leprosy bacillus. The oil has been used against leprosy since antiquity.

In I9I6 Sir Leonard Rogers suggested that chaulmoogra oil might be effective against tuberculosis and found pyrexia, reactions in the lesions and changes in the bacteria after its administration.

Following the introduction of gold therapy in chronic arthritis, it seemed possible that chaulmoogra oil might be of some value in the same condition; and accordingly a series of cases was put under treatment.

The choice of a preparation of the oil or its active principles was first considered and tentative trials were made with the ethyl esters of chaulmoogric and hydnocarpic acid. Although these are the two principal acids, there is reason to think that other as yet unidentified acids are also present and may contribute to the therapeutic value of the oil.

Various doses were experimented with. It was found that these ethyl esters of chaulmoogra oil were of little value in either of the main groups of arthritis ; and chaulmoogra oil itself was therefore tried.

Small series of cases of rheumatoid or infective arthritis (which we are unable at present to distinguish satisfactorily) were not sufficiently impressive to justify its continuation and it was decided to try the oil in cases of osteoarthritis. After two years' experience it seems that the results are sufficiently good to be set down in detail.

Other workers have recorded their findings. McIlkenny (I93I) observed that infective arthritis is not met with in leprosy cases treated with chaulmoogra oil and he employed it in a limited number of cases belonging to the infective, osteoarthritic and mixed groups of arthritis with some success.

Hebert (I933) used the oil in the infective type and, in a series of fifty-seven cases, found improvement in nearly all of them by the second week; the average patient became symptom-free in about 8 weeks. He used a mixture of crude chaulmoogra oil with Io per cent. olive oil and 0.2 per cent. benzocaine, and found that the treatment should be continued for some time after the patients became symptom-free.

As stated above, these results have not been obtained in the infective type of arthritis and the use of the oil has been confined to cases of hypertrophic or osteoarthritis.

\section{Clinical Material.}

No attempt has been made to pick the cases and the first 20 cases that attended were chosen for the treatment. 
Table I gives details of these cases; and Table II shows the amount of treatment that they have had with the results attained.

\section{DETAILS OF CASES TREATED.}

TABLE I.

$\begin{array}{cccc}\text { No. } & \text { Sex } & \text { Age } & \text { Weight } \\ \text { 1. } & \text { F. } & 50 & \text { Spare } \\ \text { 2. } & \text { F. } & 48 & \text { Spare } \\ \text { 3. } & \text { M. } & 61 & \text { Spare } \\ \text { 4. } & \text { M. } & 72 & \text { Spare } \\ \text { 5. } & \text { F. } & 57 & \text { Obese } \\ \text { 6. } & \text { F. } & 60 & \text { Obese } \\ \text { 7. } & \text { F. } & 50 & \text { Normal } \\ \text { 8. } & \text { F. } & 54 & \text { Obese } \\ \text { 9. } & \text { F. } & 38 & \text { Obese } \\ \text { 10. } & \text { F. } & 56 & \text { Obese } \\ \text { 11. } & \text { F. } & 62 & \text { Obese } \\ \text { 12. } & \text { F. } & 48 & \text { Spare } \\ \text { 13. } & \text { F. } & 58 & \text { Obese } \\ \text { 14. } & \text { F. } & 59 & \text { Obese } \\ \text { 15. } & \text { F. } & 66 & \text { Normal } \\ \text { 16. } & \text { F. } & 47 & \text { Obese } \\ \text { 17. } & \text { M. } & 65 & \text { Obese } \\ \text { 18. } & \text { M. } & 69 & \text { Spare } \\ \text { 19. } & \text { F. } & 72 & \text { Spare } \\ 20 . & \text { F. } & 66 & \text { Obese }\end{array}$

Joints involved

Hands and Feet

Spine and Feet

Feet

Shoulder

Knees

Knees and Shoulder

Hands and Feet

Knees

Knees and Feet

Knees

Knees

Knees

Generalised

Lumbar Spine

Knees

Elbows and Hands

Knees

Hips and Knees

Knees

Hips

$\begin{array}{cl}\begin{array}{c}\text { Blood } \\ \text { Sedimentation Rate } \\ \text { (mms. at one hour) }\end{array} & \text { Blood Pressure } \\ 3-8 & 128 / 80 \\ 6 & 160 / 100 \\ 3 & 134 / 80 \\ 2 & 120 / 80 \\ 7 & 190 / 110 \\ 2 & 136 / 74 \\ 4 & 130 / 70 \\ 6-11 & 180 / 110 \\ 3-10 & 110 / 70 \\ 4 & 190 / 100 \\ 5 & 180 / 108 \\ 1 & 130 / 80 \\ 5 & 190 / 98 \\ 4 & 210 / 120 \\ 2-10 & 140 / 85 \\ 7-18 & 190 / 70 \\ 2 & 180 / 100 \\ 10 & 120 / 84 \\ 8 & 150 / 90 \\ 5 & 125 / 75\end{array}$

TABLE II.

\begin{tabular}{|c|c|c|c|c|c|}
\hline No. & Type of Case & $\begin{array}{l}\text { Time under } \\
\text { Treatment }\end{array}$ & $\begin{array}{l}\text { No. of } \\
\text { Injections }\end{array}$ & $\begin{array}{l}\text { Quantity of } \\
\text { oil used }\end{array}$ & Result \\
\hline 1. & Rheumatoid Osteoarthritis & Five months & 16 & $62 \mathrm{ccs}$ & $\begin{array}{l}\text { Symptom free while she had } \\
\text { injections. }\end{array}$ \\
\hline 2. & $\begin{array}{l}\text { Osteoarthritis (at time of } \\
\text { menopause) }\end{array}$ & One month & 5 & 10, & No improvement. \\
\hline 3. & Osteoarthritis (due to gout) & One month & 3 & 15, & Improved. \\
\hline 4. & $\begin{array}{c}\text { Osteoarthritis (due to } \\
\text { trauma) }\end{array}$ & Two months & 7 & 37, & Improved. \\
\hline 5. & Osteoarthritis & Two months & 7 & 15, & "Clinical cure." \\
\hline 6. & Osteoarthritis & Five months & 15 & 57, & Improved (skin irritation). \\
\hline 7. & Rheumatoid Osteoarthritis & Four months & 15 & 31, & No improvement. \\
\hline 8. & Osteoarthritis & Nine months & 36 & 169, & "Clinical cure." \\
\hline 9. & Osteoarthritis (spine $\underset{\text { knees) }}{\&}$ & $\begin{array}{l}\text { Thirteen } \\
\text { months }\end{array}$ & 52 & 341, & Improved. \\
\hline 10. & Osteoarthritis & Two weeks & 2 & 7 & $\begin{array}{l}\text { Injections stopped because of } \\
\text { faintness and sickness. }\end{array}$ \\
\hline 11. & Osteoarthritis & Nine $m$ & 9 & 31, & Improved. \\
\hline 12. & Osteoarthritis & Eight months & 32 & 117, & Improved. \\
\hline 13. & Osteoarthritis & Five months & 10 & 35, & $\begin{array}{l}\text { Improved, except one small } \\
\text { joint of the hand. }\end{array}$ \\
\hline 14. & Osteoarthritis & Two months & 7 & 24, & Improved. \\
\hline & Osteoar & $\begin{array}{l}\text { Two and a } \\
\text { half months }\end{array}$ & 10 & 32, & Improved. \\
\hline 16. & $\begin{array}{l}\text { Osteoarthritis } \\
\text { (Occupational) }\end{array}$ & Eight & 30 & & Impr \\
\hline 17. & Osteoarthritis & One month & 4 & 15, & No improvement. \\
\hline 18. & Osteoarthritis & Three months & 12 & 59, & Improved. \\
\hline 19. & Osteoarthritis $\begin{array}{c}\text { (Diabetes } \\
\text { mellitus) }\end{array}$ & Three & 12 & 43, & \\
\hline 20. & Osteoarthritis (Traumatic) & Two months & 9 & 49, & $\begin{array}{l}\text { Improved, but injection site } \\
\text { became sore and she relapsed. }\end{array}$ \\
\hline
\end{tabular}




\section{Clinical Investigation.}

Each case has been thoroughly examined from every point of view and the importance of such an examination cannot be over-emphasised in cases of chronic arthritis.

In every case the blood sedimentation rate has been determined and $\mathrm{X}$-rays have been taken of a sufficient number of joints to determine the diagnosis in conjunction with the other factors available.

In a number of cases the blood uric acid has been determined but in only one case, where the diagnosis of gout had already been made on clinical grounds coupled with the radiological findings, was the figure raised.

In a few cases complete blood counts were carried out, but in all cases a hæmoglobin estimation was made, as the occurrence of a secondary anæmia is considered important.

The basal metabolic rate was determined in two cases and both were within the limits of normality. The Wassermann reaction was negative in all cases where it was done.

\section{Method of Preparation and Dosage.}

All the injections were given intramuscularly into the glutei and at the commencement the complaint was frequently heard that the injections were painful. It was therefore decided to add a local anæsthetic to the oil. Eventually Scuroform (May \& Baker) was used as being the most effective. Scuroform is the normal butyl ester of p-amino-benzoic acid and is almost insoluble in water, but is soluble in oil. A saturated solution in olive oil contains about 8 per cent. On account of its insolubility in water it is almost devoid of toxicity.

The final mixture used was 0.5 per cent. of Scuroform in chaulmoogra oil. After the addition of this local anæsthetic to the oil no further complaints were heard of any pain after the injections and it appeared to be completely effective.

At first the oil was put up in $8 \mathrm{oz}$. rubber-capped bottles and the dose drawn off as required. This was not considered satisfactory and now small bottles are used and only one dose is taken out of each bottle. The bottles are autoclaved for one hour before use. It is as well to warm the oil before injection by placing the bottles in warm water, as this makes the oil easier to handle and is more comfortable for the patient.

With no previous experience of treatment with chaulmoogra oil, it was decided to start with low doses and the initial dose was I c.c. in each case. Doses were always given weekly and an increase of I c.c. was made each time. With increasing experience the idea gained ground that, in some cases, the doses were too small, so that now, after the initial dose, an increase of 2 c.cs is made each time until 9 c.cs have been reached, unless there are indications to the contrary.

In some cases, in particular No. 8 in this series, a smaller dose than Io c.cs was found to be ineffective. This case eventually became symptom free.

The largest dose given so far is 20 c.cs.

There does not appear to be any relationship between the dose of the drug tolerated and the weight of the patient. 


\section{Complications.}

One of the great advantages of the treatment is that the complications are rare and very mild.

Occasionally complaint is made of a feeling of itching all over the body which lasts a day or two after the injection, but apart from this and one case in which the injection site became sore, there have been no complications.

\section{Results.}

Table II shows the results in the various cases after dissection. The two cases labelled "well " are both housewives and do their own housework and say they are perfectly well. The knees were affected in both cases and they belong to that type of osteoarthritis which is associated with high blood pressure. In one case (No. 8) obesity was also present.

One case only keeps well while the injections are continued and she has done all her own work and had no symptoms for two years.

Twelve cases were improved, in the sense that they had no symptoms, but would not go so far as to say they were quite well. In all these cases swelling, if present, had disappeared, and joint movements were free and painless.

In four cases no improvement took place, and in one there was an idiosyncrasy to the drug and the injections had to be stopped.

Out of twenty cases, therefore, fifteen or 75 per cent. showed great improve- $\sigma \frac{\pi}{5}$ ment with this treatment.

\section{Summary.}

Twenty cases of chronic arthritis have been treated by injections of chaulmoogra oil intramuscularly.

The group is analysed to show the types to which the various cases belong, details are given of the amount of oil administered and the results are shown.

Chaulmoogra oil is found to be superior to any other single medicament in the treatment of osteoarthritis, but to have a very limited field in cases of rheumatoid or infective arthritis.

\section{REFERENCES.}

